\title{
Gentamicin coating of nanotubular anodized titanium implant reduces implant-related osteomyelitis and enhances bone biocompatibility in rabbits [Corrigendum]
}

\author{
Liu D, He C, Liu Z, Xu W. International Journal of \\ Nanomedicine. 2017;12:5461-5471.
}

On page 5469, Acknowledgments section, 4th row from the bottom should read "This study was supported by the National
Natural Science Fund (81371936) and Shanghai Committee of Science and Technology, China (14JC1493102)" rather than "This study was supported by the National Natural Science Fund (81371936, 14JC1493102)".
International Journal of Nanomedicine

\section{Publish your work in this journal}

The International Journal of Nanomedicine is an international, peerreviewed journal focusing on the application of nanotechnology in diagnostics, therapeutics, and drug delivery systems throughout the biomedical field. This journal is indexed on PubMed Central, MedLine, CAS, SciSearch ${ }^{\circledR}$, Current Contents ${ }^{\circledR} /$ Clinical Medicine,

\section{Dovepress}

Journal Citation Reports/Science Edition, EMBase, Scopus and the Elsevier Bibliographic databases. The manuscript management system is completely online and includes a very quick and fair peer-review system, which is all easy to use. Visit http://www.dovepress.com/ testimonials.php to read real quotes from published authors. 